\title{
British imperial expansion and the transformation of violence at sea, 1600- 1850: introduction
}

Article

Published Version

Blakemore, R. J. (2013) British imperial expansion and the transformation of violence at sea, 1600-1850: introduction. International Journal of Maritime History, 25 (2). pp. 143-145. doi: https://doi.org/10.1177/084387141302500211 Available at http://centaur.reading.ac.uk/71906/

It is advisable to refer to the publisher's version if you intend to cite from the work. See Guidance on citing.

Published version at: http://journals.sagepub.com/doi/abs/10.1177/084387141302500211\#

To link to this article DOI: http://dx.doi.org/10.1177/084387141302500211

Publisher: International Maritime Economic History Association

All outputs in CentAUR are protected by Intellectual Property Rights law, including copyright law. Copyright and IPR is retained by the creators or other copyright holders. Terms and conditions for use of this material are defined in the End User Agreement. 


\section{www.reading.ac.uk/centaur}

\section{CentAUR}

Central Archive at the University of Reading

Reading's research outputs online 


\title{
FORUM
}

\section{British Imperial Expansion and the Transformation of Violence at Sea, 1600-1850: Introduction ${ }^{1}$}

\author{
Richard J. Blakemore
}

This forum is the product of a panel at the Sixth International Congress of Maritime History at the University of Ghent, 2-6 July 2012, which in turn emerged from the Maritime and Oceanic History Graduate Workshop at the University of Cambridge. All the contributors are or have been conveners of this workshop, and although engaged on individual projects, the wide variety of papers we have hosted has revealed some generally recurring themes relevant to all of our work. Unsurprisingly, one of the most important can be described, in a broad sense, as "sea power." The conduct, control and conceptualization of force - usually through violence - across maritime spaces is a fascinating area of study with implications for a range of historical subjects: empire, commerce, globalization and cultural interaction, to name just a few.

"Sea power" has certainly had its fair share of historical investigation, and it is impossible to offer a full account here. Probably the most influential works have been Alfred Mahan's late nineteenth-century study, dominating the field for decades, and Frederick Lane's argument that "protection costs" are a critical element of commerce and states' control over it. ${ }^{2}$ There was for a long time (and to some extent remains) a tendency, following Mahan, to associate

${ }^{1}$ The contributors would like to thank the organizers of the Sixth International Congress, especially Professor Lewis Fischer, who encouraged us to submit this forum, and all of the participants at our workshop over the past four years.

${ }^{2}$ Alfred T. Mahan, The Influence of Seapower upon History, 1660-1783 (Boston, 1890; reprint, New York, 1987); and Frederic C. Lane, "National Wealth and Protection Costs" and "The Economic Meaning of War and Protection," both in Venice and History: The Collected Papers of Frederic C. Lane (Baltimore, 1966), 372-398. See also Niels Steensgaard, "Violence and the Rise of Capitalism: Frederic C. Lane's Theory of Protection and Tribute," Review (Fernand Braudel Centre), V, No. 2 (1981), 247-273.

International Journal of Maritime History, XXV, No. 2 (December 2013), 143-145. 
"sea power" principally with state navies, but Lane showed that naval and mercantile affairs cannot be so easily separated. ${ }^{3}$ More recently, historical, geographical and legal scholars have turned their attentions to the uses of "extraterritorial" violence by the expanding European empires of the early modern period in their contests and commerce with one another and with the societies of other global regions. ${ }^{4}$

It is in this spirit of studying interconnected political, economic and cultural factors that this forum presents six essays examining various, and often unexplored, dimensions of maritime violence within British imperial expansion from the beginning of the seventeenth until the mid-nineteenth century. The British Empire is, like sea power, an intensively-researched topic - indeed, it is usually regarded as achieving, by the nineteenth century, the apogee of worldwide sea power. ${ }^{5}$ Yet perhaps because of this later dominance (and the role within it of the Royal Navy), the story of imperial expansion and maritime violence has usually been told from the centre, looking out, although this is changing. ${ }^{6}$ In this forum we shift the perspective to two important spaces - the deck and the shoreline - to examine how actors at the edges of imperial au-

${ }^{3}$ For more recent discussions of state power and sea power, see Jan Glete, Navies and Nations: Warships, Navies and State Building in Europe and America, 1500-1860 (2 vols., Stockholm, 1993); N.A.M. Rodger, "From the 'Military Revolution' to the 'Fiscal-Naval State,'” Journal for Maritime Research, XIII, No. 2 (2011), 119-128; John F. Guilmartin, Jr., "The Military Revolution in Warfare at Sea during the Early Modern Era: Technological Origins, Operational Outcomes and Strategic Consequences," Journal for Maritime Research, XIII, No. 2 (2011), 129-137; and Gijs A. Rommelse, "An Early Modern Naval Revolution? The Relationship between 'Economic Reason of State' and Maritime Warfare," Journal for Maritime Research, XIII, No. 2 (2011), 138-150; for Britain in particular, see Daniel A. Baugh, "Great Britain's 'Blue-Water' Policy, 1689-1815," International History Review, X, No. 1 (1988), 3358.

${ }^{4}$ Two of the most important are Janice E. Thomson, Mercenaries, Pirates, and Sovereigns: State-Building and Extraterritorial Violence in Early Modern Europe (Princeton, 1994); and Lauren Benton, A Search for Sovereignty: Law and Geography in European Empires, 1400-1900 (Cambridge, 2009). For a longer perspective, see Philip E. Steinberg, The Social Construction of the Ocean (Cambridge, 2001).

${ }^{5}$ The best summary is N.A.M. Rodger, The Safeguard of the Sea: A Naval History of Britain, 660-1649 (London, 1997); and Rodger, The Command of the Ocean: A Naval History of Britain, 1649-1815 (London, 2004).

${ }^{6}$ See, for example, Miles Ogborn, Global Lives: Britain and the World, 15501800 (Cambridge, 2008); and H.V. Bowen, Elizabeth Mancke and John G. Reid (eds.), Britain's Oceanic Empire: Atlantic and Indian Ocean Worlds, c. 1550-1850 (Cambridge, 2012). 
thority were crucial in defining and enforcing that authority, through both their acts of maritime violence and their justifications of these acts.

Edmond Smith opens with an examination of English activity in the Indian Ocean at the start of the seventeenth century, demonstrating that maritime violence was not intended to achieve domination, at sea or ashore, but was part of how the East India Company (EIC) as a "supplicant" negotiated its commercial relationships with Indian and Asian authorities. In my paper I argue that piracy in the early and mid-seventeenth century Atlantic was not a qualitatively distinctive form of maritime violence but an applied label, part of the dialogue between seafarers and state (and between different states) by which the parameters of legitimate and illegitimate violence were continuously defined. Adrian Leonard moves the story on to the late seventeenth and early eighteenth centuries with the only paper looking directly at the imperial metropolis; even here, however, it is clear that non-state interests were vital, as the development of a complicated insurance market allowed the British economy to survive and even profit from its enemies' maritime violence. Derek Elliott shows how during the early eighteenth century the EIC at Bombay imposed its own definition of the region's pass system in order to delegitimize the sovereignty claimed by the Angria, a local Indian power. Joshua Newton assesses a very similar situation in West Africa at mid-century where, even by the later stages of imperial presence, competing legal systems resulted in uncertain attitudes towards seaborne violence and the exact role of the Royal Navy. Finally, Simon Layton explores the culmination of these trends in the Indian Ocean of the late eighteenth and early nineteenth century, concluding that the EIC and then the British Empire were ultimately successful in using definitions of "piracy" to impose what he calls an "imperialism of free seas."

Important continuities unite these different studies. In each case, acts of maritime violence are surrounded by a complex and negotiable political framework, created and exploited as much by those on the periphery as by those at the centre, which should not be seen just in geographical terms. In each case, the state and the Royal Navy were less the driving force than resources to be utilized. Nevertheless, British imperial expansion did bring about a transformation of maritime violence. This is not a new narrative, but our research contributes to changing its tenor and pace: slowly, cumulatively, across two and a half centuries, the accretion of Britain's sea power in a physical, legal and conceptual sense reduced the manoeuvring space of those who had once been its principal agents and crushed those who had once contested it. This, of course, would only lead to other forms of resistance - but that is another story. 